\title{
Environmental Effects of Gully Erosion in Nigeria Case Study of Nanka Community, Orumba North, L.G.A of Anambra State
}

\author{
Iliyasu M. Anzaku ${ }^{1}$ Buba Y. Alfred ${ }^{3} \quad$ Timnan Nden $^{3} \quad$ Sunny Emeson $^{3} \quad$ Oyekeshi Nkiru $^{2}$ \\ 1.School of Continuing Education, Department of Sciences, Bayero University, Kano, Nigeria \\ 2.Departments of Environmental Sciences, Nasarawa State University Keffi, Nasarawa State, Nigeria \\ 3.Nigerian Building \& Road Research Institute, 10 NBRRI Road/ I.T. Igbani Street, Jabi District, Abuja, FCT, \\ Nigeria
}

\begin{abstract}
Soil is the most vital natural resources on earth. This is because it hosts both animate and inanimate beings and over three quarters of the world's man-made developments are being carried out on land. Nanka is an Igbo speaking community covering five (5) settlements in Orumba North Local Government Area of Anambra State, South Eastern Nigeria. The studyis aimed at evaluating the effects of gully erosion in Nanka Community of Anambra State and with a view to recommend sustainable mitigation measures for environmental improvement. The use of questionnaires, maps, pictures, literature review, soil sample collection and laboratory analysis were part of the research methodology. The study revealed that both the natural and anthropogenic such as road construction without drainage, deforestation, solid waste disposal in water ways, rainfall intensity and nature of soil among others are the causal factors of gully erosion in Nanka Community. The respondents agreed that rainfall intensity and nature of soil are the major cause with about $36.02 \%$ and $30.11 \%$ respectively. At 0.05 level of significance, the critical table value of ${ }^{\prime} t$ test' is 2.78 while the calculated value of $\mathrm{R}^{2}$ is $0.31(31 \%)$ for the test of hypothesis. However, it was also observed that the effects of gully erosion in Nanka Community encompass destruction of residential homes, psychological trauma and loss of lives and farmlands among others. The mitigation measures to tackle the problem are land reclamation, aforestation, construction of roads with drainages, removal solid waste materials in water channels, public sensitization / awareness campaign and construction of embankments through public and private participation programme.
\end{abstract}

Keywords: Aforestation, Anthropogenic factors, Gully erosion, Mitigation, Rainfall

DOI: $10.7176 / \mathrm{JEES} / 9-10-08$

Publication date:October $31^{\text {st }} 2019$

\subsection{INTRODUCTION}

Soil is the most vital natural resources on earth. This is because it hosts both animate and inanimate beings and over three quarters of the world's man-made developments are on it (Okin, 2005). Unfortunately, over 65 percent of the soil on earth is said to have displayed degradation phenomena as a result of soil erosion. Soil erosion is the most threatening environmental degradation problem in the developing world (Ananda and Herath, 2003). It is identified as one of the direct causes of environmental degradation and poverty in many parts of the world (Beijing Times, 2002). And it threatens sustainability of both plant and animals in the world. Soil erosion is a complex process encompassing detachments, transportation and deposition of weathered materials from one point to another by denuding agents like winds, water and mostly man through his activities, It is an environmental problem that can be attributed to both natural and human factors, upon which its extent and form is determined (Egboka, 2003; Onwuka, 2008).

The World Bank (1990) recognized three main environmental problems facing Nigeria: soil degradation and loss, water contamination and deforestation. In addition, other problem areas were specified: gully erosion, wildlife and biodiversity losses, air pollution and the spread of the water hyacinth. Gully erosion contributes to each of the three main problems and causes damage with an annual cost to the nation, estimated at $\$ 100$ million in 1990 (World Bank, 1990). According to World Bank report, "while there is much awareness in the country of environmental concerns, Nigeria's institutional ability to address them remains weak with population skyrocketing, cities expanding and greater number of Nigerians depending on a shrinking pool of arable land, degradation continues to worsen." Unfortunately, the situation has not changed significantly in 2010 , fifteen years later. As at 1997, there were 5,700 erosion sites nationwide and 4,000 of these were in south eastern States (UNDP, 1997). This figure has certainly increased. In 2009, the World Bank Country report on Nigeria still listed gully erosion as one the top five major hazards threatening the Nigerian environment. Numerous new gullies have emerged and many of the old gullies have grown rapidly to disaster levels. The Nanka erosion gullies in Anambra State are the most complex single erosion site in the whole world (UNDP, 1997). From the above, it is very clear that the problem of soil gully erosion/degradation is of staggering dimension.

In south eastern Nigeria, gully erosion is responsible for the widespread degradation of arable land, 
destruction of homes, transportation and communication systems, contamination of water supply, isolation of settlements, migration of communities etc. The whole of South Eastern Geopolitical Zone is ravaged by gully erosion just as desertification threatens the North and crude oil-related pollution wrecks the Niger Delta but Anambra States condition has evolved to an epidemic intensity.
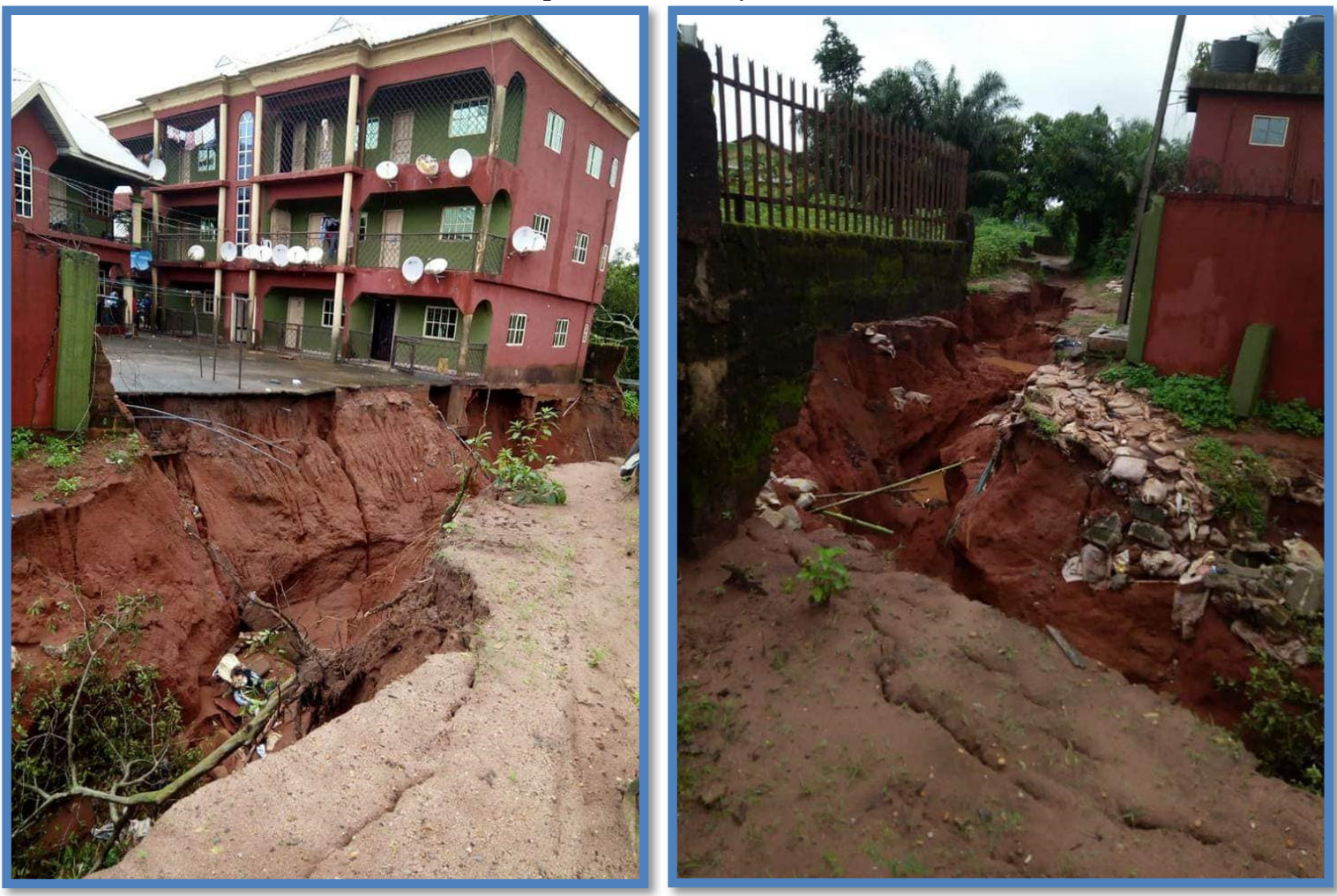

Plate 0.1: Gully Erosion Affecting the Environment in Niger Delta, Nigeria

Enabor and Sagna (1986) viewed gully erosion from its social disequilibrium angle by saying that gully soil erosion entails the steady destruction of community. Akamigho (1986), in his contribution said that gully erosion kills and makes refugees, wrecks our economy, shatters industrial developments, creates low food production, degrades environment and makes the future very bleak.

Gully erosion really hampers socio-economic activities in affected areas of the world. In agriculture, it depletes the inorganic nutrients like nitrogen, phosphate, potassium and calcium present in the soil. It also carries away the organisms living in the soil, as a result of which the soil performs poorly. This is because plant growth is stunted and crop yield declines. Again, because of gully erosion, related loss of productivity and increased population growth, the per capital food supply has been reduced over the past ten years and continues to fall (Sodhi, 2005). It has also affected commercial and many economic activities. A lot of industrial activities and industries have been affected by erosion menace. In transportation, a lot of roads have been destroyed and some is being threatened. But as Onwuka, (2008) argued, the understanding of the root causes of soil erosion in any place makes its control a reality. It is on this premise that this study seeks to ascertain the role of soil characteristics in gully erosion menace using Nanka, Orumba North LGA of Anambra state as case study.

\subsection{THE STUDY AREA AND METHODOLOGY}

\subsection{Study Area Location}

Nanka (pronounced as Nan-ka by the natives), is an Igbo speaking town in South Eastern Nigeria. It is one of the 16 major towns that constitute Orumba North Local Government Area of Anambra State with an estimated population of about 43,157 (NPC, 1991, EGR applied). The total land mass of Nanka is $45.632 \mathrm{~km}^{2}$ and its geographic coordinates are latitude $6^{0} 03^{\prime} 00$ North and longitude $7^{0} 05^{\prime} 00$ East. The area is bounded on the North by Nise and Mbaukwu, on the South by Ekwulobia, on the East by Oko, Amaokpala and Ogbu (Awgbu) and on the West Akwaeze, Neni and Adazi. A major tarred road running from Amawbia-Awka to Ekwulobia with other minor untarred roads and footpaths help to connect the gully complex.It comprises seven villages including Agbiligba, Enugwu, Ifite, Amako, Ududo, Ubahu, and Isiakpueni. 


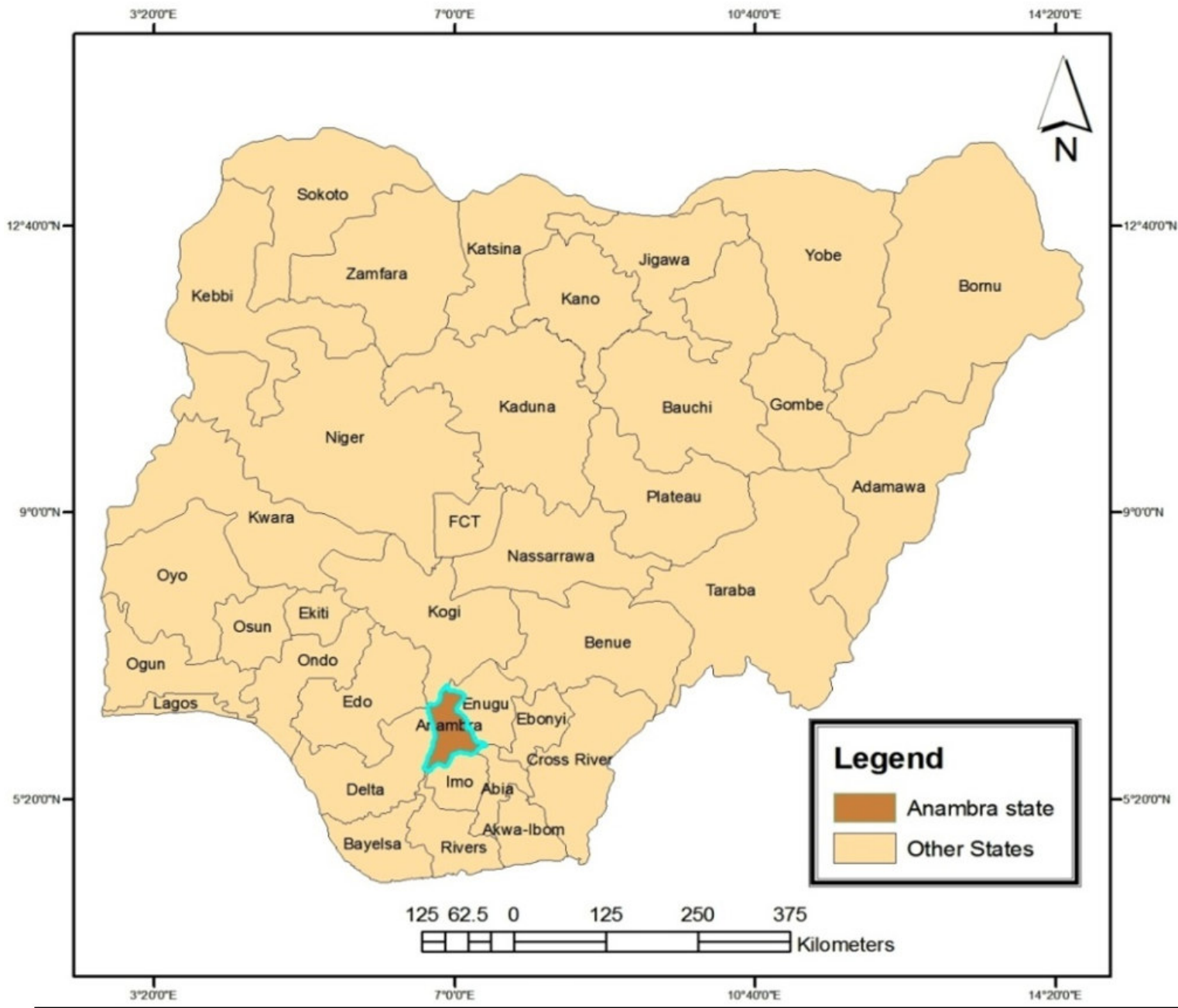

Figure 2.1 Map of Nigeria showing Anambra State where the study area is located

Source: Egboka, B.C. E (1993) “The Raging War” 


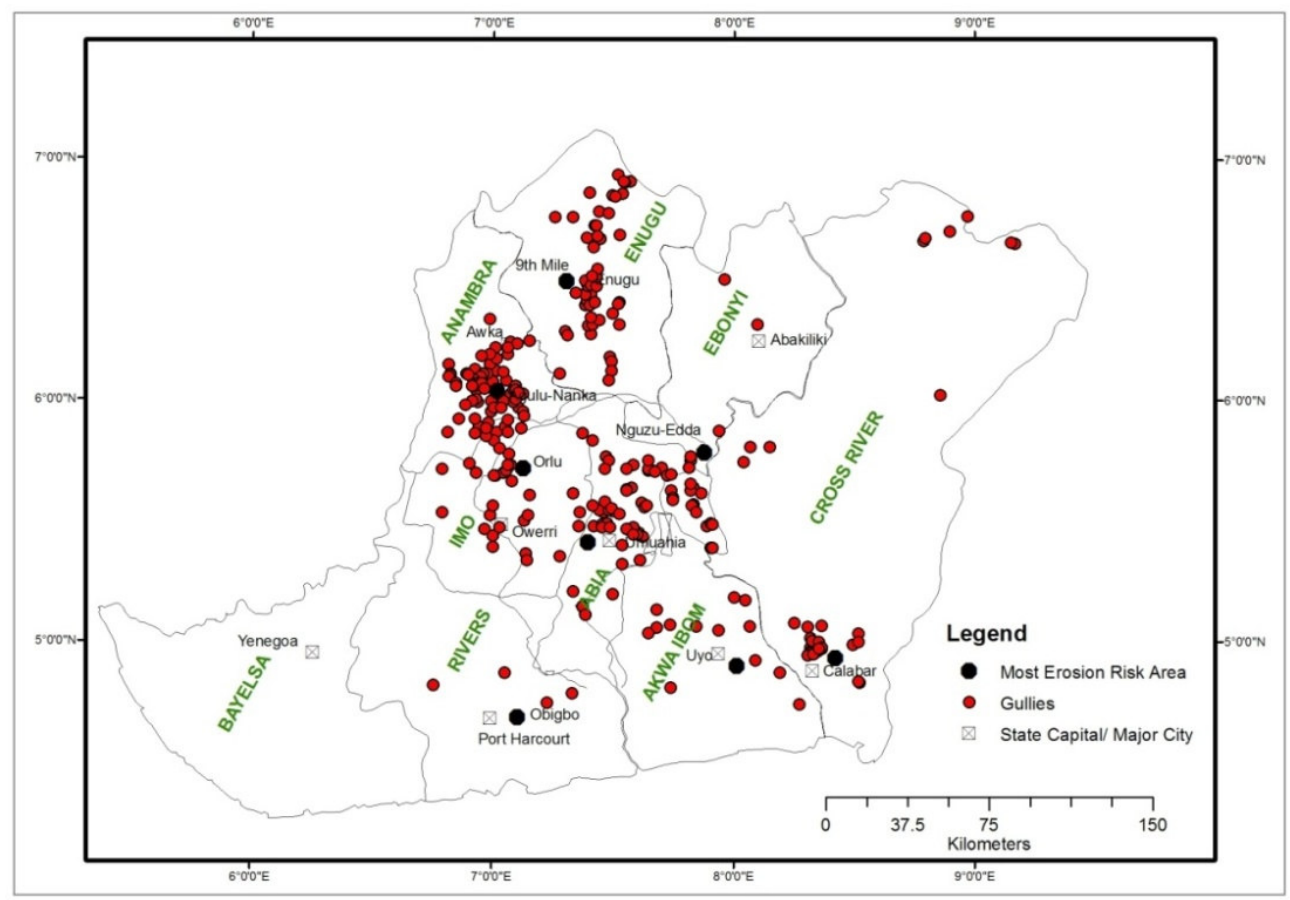

Figure 2.2: Niger Delta Region of Nigeria showing some States affected by Gully Erosion with Anambra State having the highest points of Gully Erosion.

Source: Egboka, B.C. E (1993) "The Raging War"

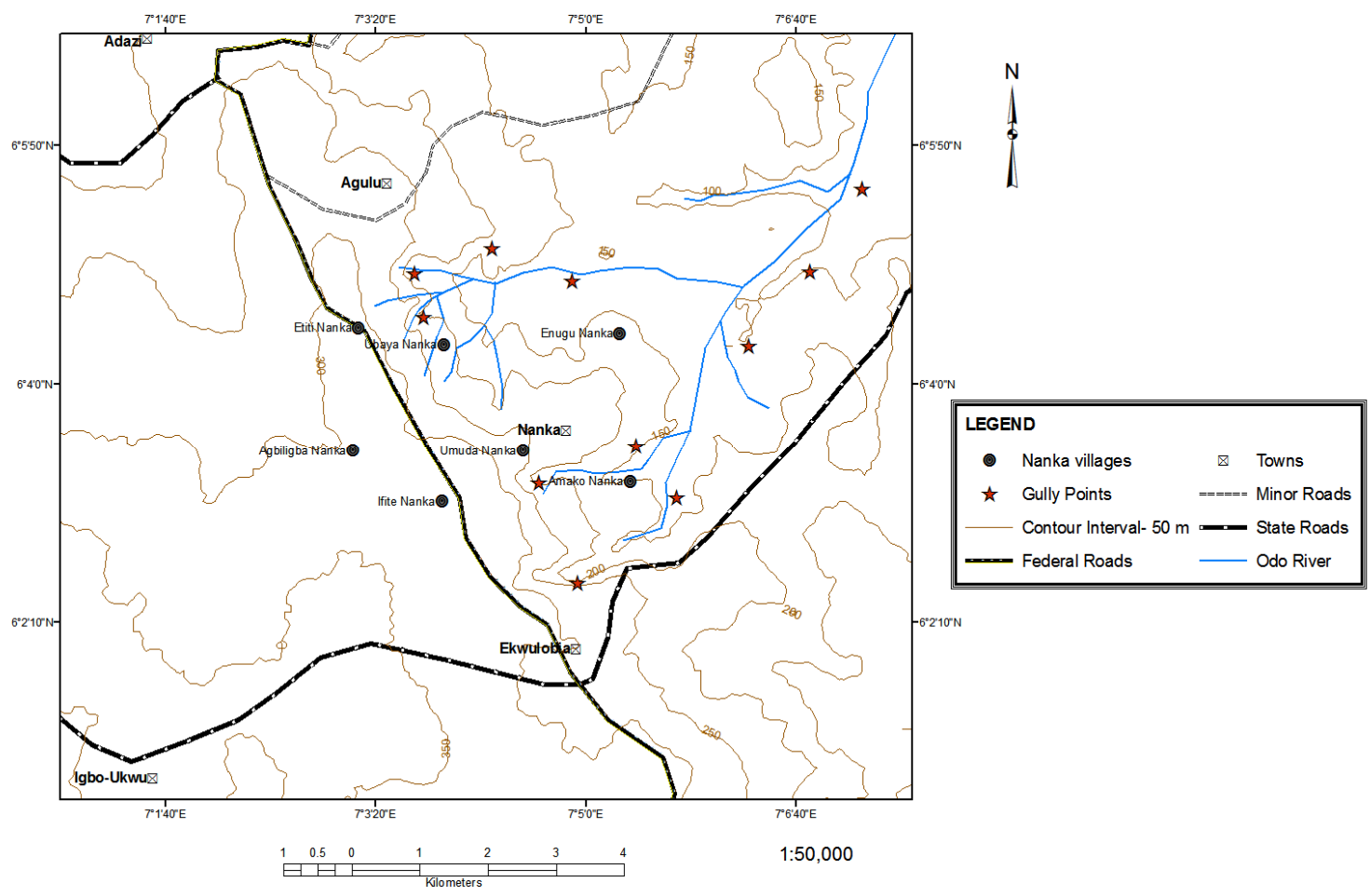

Figure 2.3: Identification and Mapping of gully erosion sites in Nanka Source: AAGIS, 2015

\subsection{Materials and Method}

To undertake this study, the following were applied: Reconnaissance Survey, Research design, data Needs and Sources, Data Collection, Research Population, Sampling Method, Sample size Data Collection Instrument and Method of Data analysis. 


\subsubsection{Reconnaissance Survey}

A reconnaissance survey was carried out to ascertain the nature of the erosion taking place in the area as well as knowing the types of vegetation cover in the area. This was made possible using the map of the study area.

\subsubsection{Research Design}

The study is non-experimental in design, because it will portray the current impact of gully erosion on the affected people of Nanka, South-eastern Nigeria. The study is descriptive survey research as opinion will be sampled with the use of questionnaires and measurement by the researcher. The respondents were given opportunity to express their opinions in the questionnaire.

\subsubsection{Sources of Data}

Primary Source

Primary source of data are direct observation from field work, oral interview and the use of questionnaire.

\section{Secondary Source}

Secondary sources of data include topographic maps, to be used to ascertain the study location and produce a geologic sedimentological map of the area. More so, library materials such as journals, published and unpublished B.Sc. M.Sc. and Ph.D thesis, text books and conference papers were used particularly during literature review.

\subsubsection{Field Measurement of Areas Affected by Gully Erosion}

Measuring instruments such as ranging poles, compass, pegs and tape were used to measure the identified gully erosion site in the study area. With the help of the aforementioned measuring instruments, the length, depth, width, slope and angle of each identified erosion site were determined in meter and were used for analysis to determine the volume of eroded soil in each of the gully site.

\subsubsection{Collection of Soil Samples from selected gullies}

With the aid of soil auger, soil samples were collected in each identified gully site in the study area. The samples were collected at depth of 50-100 cm for particle size analysis.

\subsubsection{Laboratory Analysis of Soil}

To determine the particle size of the collected soil samples, Hydrometer method was used to carry out the analysis of the soil samples. This method quantitatively determines the physical proportions of three sizes of primary soil particles as determined by their settling rates in an aqueous solution using a hydrometer. Proportions are represented by stated class sizes: sand ranging from $2000-50 \mathrm{um}$; silt ranging from $50-2.0$ um and clay $<2.0$ um (USDA Soil Survey).

\subsubsection{Determination of Erodibility Factor and Predicted Soil Loss}

$$
\mathrm{K}(\%)=\frac{(\% \text { Sand }+\% \text { Silt })}{(\% \text { Clay })} \times 100
$$

The predicted soil losses for the various areas will be done using revised universal soil loss (RUSLE) equation.

$$
\mathrm{A}=2.24 \mathrm{RK}
$$

Where $-\mathrm{A}=$ soil loss converted to ton/ha/yr by multiplying by 2.24

$$
\begin{aligned}
& \mathrm{R}=\text { Rainfall factor and given as } 0.5 \mathrm{H} \\
& \mathrm{H}=\text { Mean annual rainfall } \\
& \mathrm{K}=\text { Erodibility factor }
\end{aligned}
$$

\subsubsection{Questionnaires Administration}

Questionnaire is the major instrument for data sourcing. Sets of structured questionnaire were designed to gather information on the causes, effects and control measures of gully erosion in the area. A total number of 400 questionnaires were administered to the respondents within 14 days interval. The number of questionnaires returned is 372 while 28 were lost (see table 3.1). The questionnaires were designed to elicit information on the following:

a. Causes of soil erosion in the study area.

b. The effects of the gully in the study area.

c. The mitigation measures employed by the community in curbing or curtailing the spread of the gully in the study area.

A trial study was carried out with the questionnaire administered to five (5) respondents to each of the study area and proved that most of the respondents are uneducated and needed explanation to the questions. The questions were divided into sections A and B. Section A is the general questions, section B is the questions on the effects.

\subsubsection{Sampling Method and Sample Size}

Simple random sampling was adopted in the course of this research for the purpose of selecting households and respondents affected by gully erosion living at the gully proximate areas. 400 Respondents were selected from heterogeneous populations that make up gully affected migrants and other unaffected living populations of Nanka area. Respondents comprise only of men and women from Isiakpuenu-Nanka, Ududo-Nanka, Enugwu-Nanka, Ubahu-Nanka and Amako-Nanka communities of the area. 
Table 1.2: Collation of Questionnaire Instrument.

\begin{tabular}{|l|l|l|l|l|}
\hline Erosion Area & $\begin{array}{l}\text { Number } \\
\text { Distributed }\end{array}$ & $\begin{array}{l}\text { \% of the No. } \\
\text { Distributed }\end{array}$ & $\begin{array}{l}\text { Number } \\
\text { Collected }\end{array}$ & \% Returned \\
\hline Isiakpuenu - Nanka & 80 & 20 & 80 & 100 \\
\hline Ududo- Nanka & 80 & 20 & 80 & 100 \\
\hline Enugwu - Nanka & 80 & 20 & 78 & 97.5 \\
\hline Amako - Nanka & 80 & 20 & 62 & 77.5 \\
\hline Ubahu - Nanka & 80 & 20 & 72 & 90.0 \\
\hline Total & $\mathbf{4 0 0}$ & $\mathbf{1 0 0}$ & $\mathbf{3 7 2}$ & $\mathbf{9 3 . 0}$ \\
\hline
\end{tabular}

\section{Source: Field Work, 2015}

2.2.10 Method of Data Analysis.

This section involves the use of statistical techniques in analyzing and interpreting the data/information from the responses provided by the questionnaire.

Techniques that were adopted in data analysis are those that enhanced organization, examination and presentation of treated data. Frequency tables and corresponding percentages of the frequencies were used where appropriate. The use of tables and simple percentages assisted in clear representation of existing problem conditions.

Descriptive statistical analysis was applied to deal with the methods and techniques of summarizing and describing information (data). Percentages, proportion and mean were applied to get other parameter. Test of significance was used to test the validity of the first hypothesis. Pearson's Product Moment Correlation Coefficient was also used to analyse the relationship between the length and the depth of the gully in the area as it relates to soil loss volume. While multiple linear regression equations were used to test the validity of the second hypothesis.

\subsection{RESULTS AND DISCUSSION}

3.1.1 Causes of Gully Erosion in the study area.

Numerous factors collectively distort, erode and modify the soil surface. In the study area, both natural and anthropogenic causal factors are perceived to cause gully erosion as you can see from the tables (4.1\&4.2) below.

Table 3.1: Natural causes of Soil erosion in the study area

\begin{tabular}{|l|l|l|l|l|l|l|l|}
\hline CAUSES & $\begin{array}{l}\text { Isiakpuenu } \\
\text { Nanka }\end{array}$ & $\begin{array}{l}\text { Ududo- } \\
\text { Nanka }\end{array}$ & $\begin{array}{l}\text { Enugwu } \\
\text { Nanka }\end{array}$ & $\begin{array}{l}\text { Amako } \\
\text { Nanka }\end{array}$ & $\begin{array}{l}\text { Ubahu } \\
\text { Nanka }\end{array}$ & Total & $\%$ \\
\hline Rainfall Intensity & $\mathbf{3 1}$ & $\mathbf{2 4}$ & $\mathbf{3 3}$ & $\mathbf{2 5}$ & $\mathbf{2 1}$ & $\mathbf{1 3 4}$ & $\mathbf{3 6 . 0 2}$ \\
\hline Nature of Soil & $\mathbf{2 4}$ & $\mathbf{2 2}$ & $\mathbf{1 9}$ & $\mathbf{2 3}$ & $\mathbf{2 4}$ & $\mathbf{1 1 2}$ & $\mathbf{3 0 . 1 1}$ \\
\hline Vegetation Cover & $\mathbf{1 5}$ & $\mathbf{1 9}$ & $\mathbf{1 5}$ & $\mathbf{1 2}$ & $\mathbf{1 9}$ & $\mathbf{8 0}$ & $\mathbf{2 1 . 5 0}$ \\
\hline Topography & $\mathbf{1 0}$ & $\mathbf{1 0}$ & $\mathbf{7}$ & $\mathbf{1 3}$ & $\mathbf{6}$ & $\mathbf{4 6}$ & $\mathbf{1 2 . 3 7}$ \\
\hline TOTAL & $\mathbf{8 0}$ & $\mathbf{7 5}$ & $\mathbf{7 4}$ & $\mathbf{7 3}$ & $\mathbf{7 0}$ & $\mathbf{3 7 2}$ & $\mathbf{1 0 0}$ \\
\hline
\end{tabular}

Source: Field Work, 2015

From table 3.1 above, it can be deduced that $36.02 \%$ (134) of the respondents agreed that rainfall intensity is the main natural causes of soil erosion in the study area. It can also be deduced that $30.11 \%$ of the respondents agreed that the nature of soil is one of the natural causes of soil erosion in the area. From the table also, the nature of vegetation cover and nature of topography accounted for $21.50 \%$ and $12.37 \%$ respectively.

Table 3.2 Anthropogenic causes of gully erosion in Nanka

\begin{tabular}{|c|c|c|c|c|c|c|c|}
\hline CAUSES & $\begin{array}{l}\text { Isiakpuenu - } \\
\text { Nanka }\end{array}$ & $\begin{array}{l}\text { Ududo- } \\
\text { Nanka }\end{array}$ & $\begin{array}{l}\text { Enugwu - } \\
\text { Nanka }\end{array}$ & $\begin{array}{l}\text { Amako - } \\
\text { Nanka }\end{array}$ & $\begin{array}{l}\text { Ubahu - } \\
\text { Nanka }\end{array}$ & Total & $\%$ \\
\hline $\begin{array}{l}\text { Road construction } \\
\text { without drainages }\end{array}$ & 15 & 12 & 20 & 18 & 17 & 82 & 22.04 \\
\hline Deforestation & 18 & 21 & 15 & 20 & 14 & 88 & 23.66 \\
\hline Sand Excavation & 12 & 17 & 14 & 16 & 15 & 74 & 19.89 \\
\hline $\begin{array}{l}\text { Poor Agricultural } \\
\text { practices }\end{array}$ & 9 & 8 & 7 & 11 & 9 & 44 & 11.83 \\
\hline $\begin{array}{l}\text { Animals } \\
\text { Overgrazing }\end{array}$ & 14 & 6 & 8 & 6 & 5 & 39 & 10.48 \\
\hline $\begin{array}{l}\text { Waste Disposal in } \\
\text { water channels }\end{array}$ & 12 & 8 & 10 & 8 & 7 & 45 & 12.10 \\
\hline TOTAL & 80 & 72 & 74 & 79 & 67 & 372 & 100 \\
\hline
\end{tabular}

Source: Field Work, 2015

From the table 3.2 above, it can be deduced that $22.04 \%$ the respondents believed that gully erosion in the study area was due to poor road construction. $23.66 \%$ of the respondents believed that deforestation which involves 
the clearing of land mainly for construction and building purposes contributed to the gully formation.

Furthermore, sand excavation as perceived by $19.89 \%$ of the respondents causes gully erosion in the area while $11.83 \%, 10.48 \%$ and $12.10 \%$ of the respondents opined that poor agricultural practices of the farmers, overgrazing by the animals and dumping of refuse at the water channels respectively contributed to the causes of gully erosion in the study area

From the responses derived from the causes of gully erosion in the study area, it could be inferred that the main natural and anthropogenic causes of gully erosion arerainfall intensity and deforestation respectively.

Table 3.3 Effects of Gully erosion in the study area

\begin{tabular}{|c|c|c|c|c|c|c|c|}
\hline $\begin{array}{lr}\text { EFFECTS } & \text { OF } \\
\text { GULLY EROSION }\end{array}$ & $\begin{array}{l}\text { Isiakpuenu - } \\
\text { Nanka }\end{array}$ & $\begin{array}{l}\text { Ududo- } \\
\text { Nanka }\end{array}$ & $\begin{array}{l}\text { Enugwu - } \\
\text { Nanka }\end{array}$ & $\begin{array}{l}\text { Amako - } \\
\text { Nanka }\end{array}$ & $\begin{array}{l}\text { Ubahu - } \\
\text { Nanka }\end{array}$ & Total & $\%$ \\
\hline Home Destructions & 15 & 12 & 20 & 18 & 17 & 82 & 22.04 \\
\hline $\begin{array}{l}\text { Poor scenic } \\
\text { Environment }\end{array}$ & 18 & 21 & 15 & 20 & 14 & 88 & 23.66 \\
\hline Loss of Human life & 7 & 6 & 8 & 6 & 5 & 32 & 8.60 \\
\hline $\begin{array}{l}\text { Psychological } \\
\text { Trauma }\end{array}$ & 8 & 7 & 6 & 18 & 6 & 35 & 9.40 \\
\hline Water Pollution & 8 & 10 & 12 & 8 & 17 & 65 & 17.48 \\
\hline Loss of farmlands & 9 & 8 & 6 & 8 & 7 & 38 & 10.22 \\
\hline $\begin{array}{ll}\text { Loss } & \text { of } \\
\text { infrastructure }\end{array}$ & 10 & 15 & 14 & 10 & 15 & 64 & 17.20 \\
\hline TOTAL & 72 & 75 & 68 & 80 & 77 & 372 & 100 \\
\hline
\end{tabular}

Source: Field work, 2015

From table 3.3 above, it can be deduced that the main effect of gully erosion in the study area as perceived from the responses of the indigenes is frightful scenic environment created by the gully and this accounted for $23.66 \%$ of the total responses. This is followed by the pollution of the water bodies which accounted to $17.48 \%$ of the responses. $17.20 \%$ of the respondents agreed that infrastructures are constantly being lost as a result of the gully.

More so, $13.44 \%$ of the respondents agreed that ancestral homes are being destroyed on daily basis especially during the rainy season when the impact of the gully is most spelt out, thereby threatening the inhabitants to either pack out of their ancestral homes or stand the chance of being brutally displaced. Respondents who constituted about $10.22 \%$ of the responses agreed that loss of farmland is one of the consequences faced by the community while $9.40 \%$ and $8.60 \%$ of the respondents believed that trauma and loss of relatives respectively are the consequences/effects suffered by the community as a result of the gully.

\subsection{Control Measures of the gully erosion in the study area}

Different erosion control measures have been employed by the inhabitants of the study area to check and control the problem of soil erosion menace. These measures were explained in the table below.

Table 3.4 Control measures adopted in curtailing gully erosion in Nanka community

\begin{tabular}{|l|l|l|l|l|l|l|l|l|}
\hline $\begin{array}{l}\text { CONTROL } \\
\text { MEASURES }\end{array}$ & $\begin{array}{l}\text { Isiakpuenu - } \\
\text { Nanka }\end{array}$ & $\begin{array}{l}\text { Ududo- } \\
\text { Nanka }\end{array}$ & $\begin{array}{l}\text { Enugwu } \\
\text { Nanka }\end{array}$ & $\begin{array}{l}\text { Amako } \\
\text { Nanka }\end{array}$ & $\begin{array}{l}\text { Ubahu } \\
\text { Nanka }\end{array}$ & Total & $\%$ \\
\hline Aforestation & 20 & 17 & 18 & 19 & 16 & 90 & 24.19 \\
\hline Sand Filling & 13 & 9 & 15 & 10 & 12 & 59 & 15.86 \\
\hline $\begin{array}{l}\text { Construction } \\
\text { Drainages }\end{array}$ & 17 & 14 & 12 & 15 & 17 & 75 & 20.17 \\
\hline $\begin{array}{l}\text { Construction of } \\
\text { run-off pits }\end{array}$ & 15 & 19 & 13 & 15 & 12 & 74 & 19.89 \\
\hline $\begin{array}{l}\text { Clearing of water } \\
\text { channels }\end{array}$ & 12 & 11 & 17 & 18 & 16 & 74 & 19.89 \\
\hline TOTAL & 77 & 78 & 75 & 80 & 74 & 372 & 100 \\
\hline
\end{tabular}

Source: Field work, 2015

Table 3.4 above, presents information on the measures adopted in curtailing gully erosion in the study area. From the table, $24.19 \%(90)$ of the respondents, agreed that the main control measure adopted by the people of the community in combating the gully is aforestation while $19.89 \%$ of the respondents agreed that the construction of run-off pits as well as clearing of the water channels are the control measure adopted in the fight to control the spread of the gully. However, $20.17 \%$ of the respondents are of the opinion that construction of a good drainage network contributed to the control measure employed by the community in the fight against the gully. Again, $15.86 \%$ of the respondents believed that sand filling is one of the control measures adopted by the community in 
the control of the gully. From the study, it could be inferred that aforestation is the major practice that has been imbibed by the community in their bid to combat the gully erosion.

\subsection{Measurement of gully}

Gullies of different dimensions were found and measured by a researcher in the study area. The measurement was divided into three dimensions of length, depth and width. This measurement was taken in order to determine the volume of soil loss in the gully erosion site.

Table 3.5 showing the measurement of the gully from different localities of the study area

\begin{tabular}{|c|c|c|c|c|c|c|}
\hline $\mathbf{S} / \mathbf{N}$ & LOCATION & & LENGTH(M) & DEPT (M) & WIDTH (M) & $\begin{array}{l}\text { AV. SLOPE } \\
\text { Gradient ( }\left(^{(}\right)\end{array}$ \\
\hline 1 & Isiakpuenu - Nanka & $\begin{array}{l}\text { A1 } \\
\text { A2 } \\
\text { Mean }\end{array}$ & $\begin{array}{l}25.0 \\
40.0 \\
32.5\end{array}$ & $\begin{array}{l}65.0 \\
40.0 \\
52.5\end{array}$ & $\begin{array}{l}25.0 \\
20.0 \\
22.5\end{array}$ & $65^{\circ}$ \\
\hline 2 & Enugwu - Nanka & $\begin{array}{l}\text { B1 } \\
\text { B2 } \\
\text { Mean }\end{array}$ & $\begin{array}{l}32.0 \\
15.0 \\
23.5\end{array}$ & $\begin{array}{l}40.0 \\
44.0 \\
42.0\end{array}$ & $\begin{array}{l}17.0 \\
15.0 \\
16.0\end{array}$ & $36^{\circ}$ \\
\hline 3 & Ududo- Nanka & $\begin{array}{l}\text { C1 } \\
\text { C2 } \\
\text { Mean }\end{array}$ & $\begin{array}{l}40.0 \\
76.0 \\
58.0\end{array}$ & $\begin{array}{l}70.0 \\
50.0 \\
60.0\end{array}$ & $\begin{array}{l}21.0 \\
35.0 \\
28.0\end{array}$ & $50^{\circ}$ \\
\hline 4 & Amako - Nanka & $\begin{array}{l}\text { D1 } \\
\text { D2 } \\
\text { Mean }\end{array}$ & $\begin{array}{l}31.0 \\
25.0 \\
28.0\end{array}$ & $\begin{array}{l}45.0 \\
48.0 \\
46.5\end{array}$ & $\begin{array}{l}22.0 \\
13.0 \\
17.5\end{array}$ & $30^{\circ}$ \\
\hline 5 & Ubahu - Nanka & $\begin{array}{l}\text { E1 } \\
\text { E2 } \\
\text { Mean }\end{array}$ & $\begin{array}{l}25.0 \\
33.0 \\
29.0\end{array}$ & $\begin{array}{l}52.0 \\
25.0 \\
38.5\end{array}$ & $\begin{array}{l}16.0 \\
25.0 \\
20.5\end{array}$ & $25^{\circ}$ \\
\hline 6 & Average Mean & & 34.2 & 48.0 & 20.8 & 41.2 \\
\hline & SD & & 14.39 & 10.15 & 4.2 & 14.55 \\
\hline & CV \% & & 42.1 & 21.1 & 20.2 & 35.3 \\
\hline
\end{tabular}

\section{Source: Field work, 2015}

From the table above, it could be deduced that the severity and magnitude of the gullies in the study area are certainly not the same. For example, Gully in Ududo-Nanka seemed to be more severe than other gullies. This is because, it has the longest, deepest and widest gully among other gullies within the region with the length of $58 \mathrm{~m}$, depth of $60 \mathrm{~m}$ and width of $28 \mathrm{~m}$. This is followed by IsiakpuenuNanka which has the length of $32.5 \mathrm{~m}$, depth of $52.5 \mathrm{~m}$ and width of $22.5 \mathrm{~m}$. Other locations have varying lengths, depths and widths as the case may be.The slope gradients of the study gully site ranged from $25^{\circ}-65^{\circ}$, ordinarily under vegetal cover, these slope gradients would not enhance erosion processes as such but due to exposure to direct raindrop impact and human activities couples with poor civil engineering work to control the runoff, gully has become pronounced virtually in every catchment. 
Table 3.6The Physical and Biological Characteristics of selected Gully Erosion Sites

\begin{tabular}{|c|c|c|c|c|c|c|c|}
\hline \multirow[t]{3}{*}{ Sample Location } & \multirow{3}{*}{$\begin{array}{l}\text { Sample } \\
\text { Points }\end{array}$} & \multirow{3}{*}{$\begin{array}{l}\text { Bulk } \\
\text { Density }\end{array}$} & \multirow{3}{*}{ Texture } & \multicolumn{4}{|c|}{ Parameters Analysed } \\
\hline & & & & \multicolumn{3}{|c|}{$\begin{array}{l}\text { Particles Size } \\
\text { Distribution (\%) }\end{array}$} & \multirow[t]{2}{*}{$\begin{array}{l}\text { Organic } \text { Matter } \\
(\%)\end{array}$} \\
\hline & & & & Clay & Silt & Sand & \\
\hline $\begin{array}{l}\text { Isiakpuenu- } \\
\text { Nanka }\end{array}$ & $\begin{array}{l}\text { A1 } \\
\text { A2 } \\
\text { Mean (x) }\end{array}$ & $\begin{array}{l}1.74 \\
1.73 \\
1.74 \\
\end{array}$ & $\begin{array}{l}\text { Loamy sand } \\
\text { Loamy sand }\end{array}$ & $\begin{array}{l}8 \\
9 \\
8.5\end{array}$ & $\begin{array}{l}14 \\
12 \\
13\end{array}$ & $\begin{array}{l}70 \\
68 \\
69\end{array}$ & $\begin{array}{l}0.73 \\
0.75 \\
0.74\end{array}$ \\
\hline Enugwu - Nanka & $\begin{array}{l}\text { B1 } \\
\text { B2 } \\
\text { Mean(x) }\end{array}$ & $\begin{array}{l}1.72 \\
1.73 \\
1.73 \\
\end{array}$ & $\begin{array}{l}\text { Loamy sand } \\
\text { Loamy sand }\end{array}$ & $\begin{array}{l}7 \\
6 \\
6.5\end{array}$ & $\begin{array}{l}13 \\
12 \\
12.5\end{array}$ & $\begin{array}{l}73 \\
70 \\
72\end{array}$ & $\begin{array}{l}0.77 \\
0.80 \\
0.79\end{array}$ \\
\hline Ududo- Nanka & $\begin{array}{l}\text { C1 } \\
\text { C2 } \\
\operatorname{Mean}(x)\end{array}$ & $\begin{array}{l}1.74 \\
1.72 \\
1.73 \\
\end{array}$ & $\begin{array}{l}\text { Loamy sand } \\
\text { Loamy sand }\end{array}$ & $\begin{array}{l}7 \\
9 \\
8 \\
\end{array}$ & $\begin{array}{l}15 \\
13 \\
14 \\
\end{array}$ & $\begin{array}{l}75 \\
74 \\
74.5 \\
\end{array}$ & $\begin{array}{l}0.75 \\
0.74 \\
0.75 \\
\end{array}$ \\
\hline Amako - Nanka & $\begin{array}{l}\text { D1 } \\
\text { D2 } \\
\text { Mean(x) }\end{array}$ & $\begin{array}{l}1.72 \\
1.73 \\
1.73\end{array}$ & $\begin{array}{l}\text { Loamy sand } \\
\text { Loamy sand }\end{array}$ & $\begin{array}{l}7 \\
6 \\
6.5\end{array}$ & $\begin{array}{l}13 \\
12 \\
12.5\end{array}$ & $\begin{array}{l}73 \\
70 \\
72\end{array}$ & $\begin{array}{l}0.77 \\
0.80 \\
0.79\end{array}$ \\
\hline Ubahu - Nanka & $\begin{array}{l}\text { E1 } \\
\text { E2 } \\
\operatorname{Mean}(x)\end{array}$ & $\begin{array}{l}1.74 \\
1.73 \\
1.74 \\
\end{array}$ & $\begin{array}{l}\text { Loamy sand } \\
\text { Loamy sand }\end{array}$ & $\begin{array}{l}8 \\
8 \\
8\end{array}$ & $\begin{array}{l}14 \\
12 \\
13\end{array}$ & $\begin{array}{l}70 \\
68 \\
69\end{array}$ & $\begin{array}{l}0.73 \\
0.73 \\
0.73 \\
\end{array}$ \\
\hline Total Mean & & 1.74 & & 7.5 & 13 & 71.3 & 0.75 \\
\hline SD & & 0.34 & & 0.83 & 0.55 & 2.01 & 0.03 \\
\hline $\mathrm{CV} \%$ & & 0.24 & & 11.1 & 4.2 & 2.8 & 0.04 \\
\hline
\end{tabular}

\section{Source: Field work, 2015}

Table 3.6presents information on the results on the physical and biological characteristics of soil in the study area and the findings revealed that the soil in the study area is predominantly loamy sand with mean $\%$ value of sand being $71.3 \%$ while clay, loam and silt are $7.5 \%, 19.5 \%$ and $13 \%$ respectively. The high proportion of sand and the low proportion of clay could be attributed to the high friability and detachability nature of the soil which makes it vulnerable to agents of erosion especially under a high rainfall intensity. The organic matter content in each gully site is low and this could be attributed to the subsurface wash caused by heavy run-off water and this in consequence would not support plant growth.

The table also presents information on bulk density in the study area and it shows that the value of bulk density obtained from the gully sites ranged between $1.73-1.74 \mathrm{~g} / \mathrm{cm}^{3}$. As against the range of $2.0-$ $4 \mathrm{~g} / \mathrm{cm}^{3}$ considered for well aggregated grassland (Okogbu, 2015). This low values obtained from the sites is an indication that the soil is of highly porous nature and could not retain water, hence the erosive effect of heavy runoff will be more in the area than in other places with high bulk density.

\subsection{Volume of eroded soils in the study gully sites}

Determination of erodibility factor and predicted soil loss:

$\mathrm{K}(\%)=\frac{(\% \text { sand }+\% \text { silt })}{\% \text { Clay }} \times 100$

The predicted soil losses for the various areas were done using revised universal soil loss (RUSLE) equation. $\mathrm{A}=2.24 \mathrm{RK}$

Where $\mathrm{A}=$ soil loss converted to ton/ha/yr by multiplying by 2.24

$\mathrm{R}=$ Rainfall factor and given as $0.5 \mathrm{H}$

$\mathrm{H}=$ Mean annual rainfall

$\mathrm{K}=$ Erodibility factor 
Table 3.7 Volume of soil loss in the study gully sites

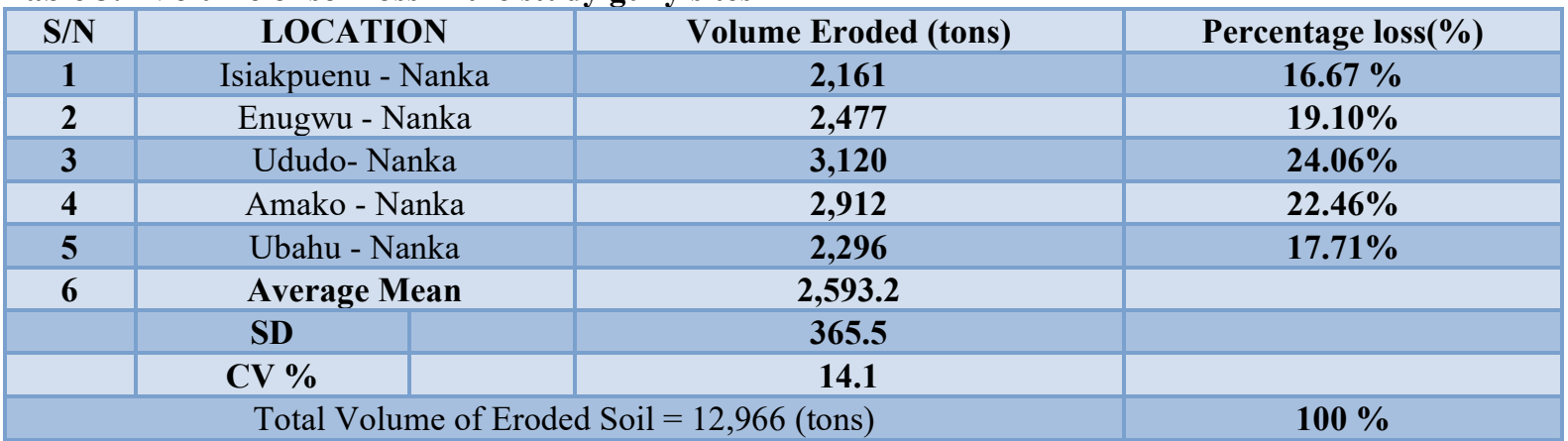

\section{Source: Field work, 2015}

Table 3.7presents information on the volume of soil loss in each of the identified gully site in the study area. The results revealed that Ududo Nanka recorded the highest volume of soil loss in the area with a soil loss of 3,120 metric tones and this accounts for $24.06 \%$ of the total soil loss in the region. This is followed by Amako Nanka which has 2,912 metric tones of soil loss and accounts for $22.46 \%$ of the total soil loss in the gully region. Enugwu Nanka, and Ubahu Nanka accounts for $19.10 \%$ and $17.71 \%$ of the total soil loss in the region respectively. The least soil loss is recorded in Isiakpuenu Nanka with a percentage loss of $16.67 \%$. From the table, it could be depicted that the total volume of the soil loss in the study area is 12,966 metric tonnes just in one year. The implication is that if no effective and immediate measures are put in place, soon there will not be any arable land left for farming and this will result in serious famine in the area. Again, all other aspect of life such as social, religious, commercial activities etc would be hampered by the loss of land.

Table 3.8 Pearson Product moment Correlation Coefficient on selected gullies in the region

\begin{tabular}{|c|c|c|c|c|c|c|}
\hline S/N & LOCATION & LENGTH $(\mathbf{M}) \mathbf{X}$ & DEPTH $(\mathbf{M}) \mathbf{Y}$ & $\mathbf{X}^{2}$ & $\mathbf{Y}^{2}$ & XY \\
\hline $\mathbf{1}$ & Isiakpuenu - Nanka & $\mathbf{3 2 . 5}$ & $\mathbf{5 2 . 5}$ & $\mathbf{1 , 0 5 6 . 2 5}$ & $\mathbf{2 , 7 5 . 2 5}$ & $\mathbf{1 , 7 0 6 . 2 5}$ \\
\hline $\mathbf{2}$ & Enugwu - Nanka & $\mathbf{2 3 . 5}$ & $\mathbf{4 2}$ & $\mathbf{5 5 2 . 2 5}$ & $\mathbf{1 , 7 6 4}$ & $\mathbf{9 8 7}$ \\
\hline $\mathbf{3}$ & Ududo- Nanka & $\mathbf{5 8}$ & $\mathbf{6 0}$ & $\mathbf{3 , 3 6 4}$ & $\mathbf{3 , 6 0 0}$ & $\mathbf{3 , 4 8 0}$ \\
\hline $\mathbf{4}$ & Amako - Nanka & $\mathbf{2 8}$ & $\mathbf{4 6 . 5}$ & $\mathbf{7 8 4}$ & $\mathbf{2 , 1 6 2 . 2 5}$ & $\mathbf{1 , 3 0 2}$ \\
\hline $\mathbf{5}$ & Ubahu - Nanka & $\mathbf{2 9}$ & $\mathbf{3 8 . 5}$ & $\mathbf{8 4 1}$ & $\mathbf{1 , 4 8 2 . 2 5}$ & $\mathbf{1 , 1 1 6 . 5}$ \\
\hline & TOTAL & $\mathbf{1 7 1}$ & $\mathbf{2 3 9 . 5}$ & $\mathbf{6 , 5 9 7 . 5}$ & $\mathbf{1 1 , 7 6 4 . 7 5}$ & $\mathbf{8 , 5 9 1 . 7 5}$ \\
\hline
\end{tabular}

Source: Field work, 2015

$$
\begin{aligned}
& \mathrm{n}=5, \sum x=171, \sum y=239.5, \sum x^{2}=6,597.5, y^{2}=11,764.75, \sum x y=8,591.75 \\
& \mathrm{r}=\quad \mathrm{n} \sum \mathrm{xy}-\left(\sum \mathrm{x}\right)\left(\sum \mathrm{y}\right) \\
& \sqrt{\left(n \sum x^{2}\right)-\left(\sum x\right)^{2}\left(2\left[\sum y^{2}\right)-\left(\sum y\right)^{2}\right]} \\
& \mathrm{r}=\quad 5(8,591.75)-(171)(239.5) \\
& V_{(5 \times 6597.5)-(171)^{2} \times(58,823.75)-(57,360.25)} \\
& \mathrm{r}=\frac{42,958.75-40,954.5}{\sqrt{(32,987.5)-(29,241) \times(58,823.75)-(57,360.25)}}
\end{aligned}
$$

$\mathrm{r}=2,004.25$

$\sqrt{5,483,002.75}$

$r=\frac{2,004.25}{2,341.58}$

$r=0.856$

In testing the validity of a formulated hypothesis, the test was applied. 


$$
\begin{aligned}
& \mathrm{t}=\frac{\mathrm{r} \sqrt{\mathrm{n}-1}=}{1-\mathrm{r}^{2}} \\
& \mathrm{t}=\frac{0.86 \sqrt{5}-1}{1-(0.86)^{2}} \\
& \mathrm{t}=\frac{0.86 \sqrt{ } 4}{1-0.74} \\
& \mathrm{t}=\frac{1.72}{0.26} \\
& \mathrm{t}=6.62
\end{aligned}
$$

The calculated value is 6.62 while the table t-value at 0.05 level of significance is 2.78 with degree of freedom 4.

\section{Test of Hypothesis 1}

Ho: There are no significant variations in the severity and magnitude of gullies in Nanka community of Orumba North L.G.A of Anambra State.

Hi: There are significant variations in the severity and magnitude of gullies in Nanka community of Orumba North L.G.A of Anambra State.

Since the calculated value is greater than the tabulated value, we accept Hi which states that there are significant variations in the sizes of gullies in the study area.

\section{Test of Hypothesis 2:}

Ho: That rainfall is not the major cause of gully erosion in Nanka at 0.05 level of significance.

$\mathbf{H}_{1}$ : That rainfall is the major cause of gully erosion in Nanka at 0.05 level of significance.

In testing the validity of Hypothesis 2, the Multiple Linear Regression Equation was used. Rainfall was taken as the dependent variable (Y) which is computed against the independent variables such as the nature of soil, the nature of vegetative cover, and the nature of topography.

The calculated value of $\mathrm{R}^{2}=0.31=31 \%$, table $\mathrm{t}$ value $=2.78$ at 0.05 level of significance. Degree of freedom $=4$. (See Appendix A)

\section{JUSTIFICATION OF RESULT}

At 0.05 level of significance, the critical table value of ' $t$ test' is 2.78 while the calculated value of $R^{2}$ is $0.31(31 \%)$. Since the calculated value of $\mathrm{R}^{2}$ is less that the critical table value, the null hypothesis (Ho) which states that rainfall is not the major natural causal factor of gully erosion in Nanka metropolis is accepted while the alternative hypothesis $\left(\mathrm{H}_{1}\right)$ which states that rainfall is the major natural causal factor of gully erosion in Nanka is rejected.

Thus, it can be deduced that despite the $36 \%$ highest rating attributed to rainfall intensity as the major cause of gully erosion in the region by the respondents, yet it could not be statistically proven to be the major cause of the gully in the study area. Hence, it could be said that others factors together join forces to cause the gully erosion. Though its incidence is aggravated during the rainy season.

Therefore, it can be inferred from the overview that apart from the rainfall intensity which aggravates the rate of erosion in the study area, other natural factors as well as other human factors collectively caused the problem of gully erosion in Nanka community of Anambra State. 


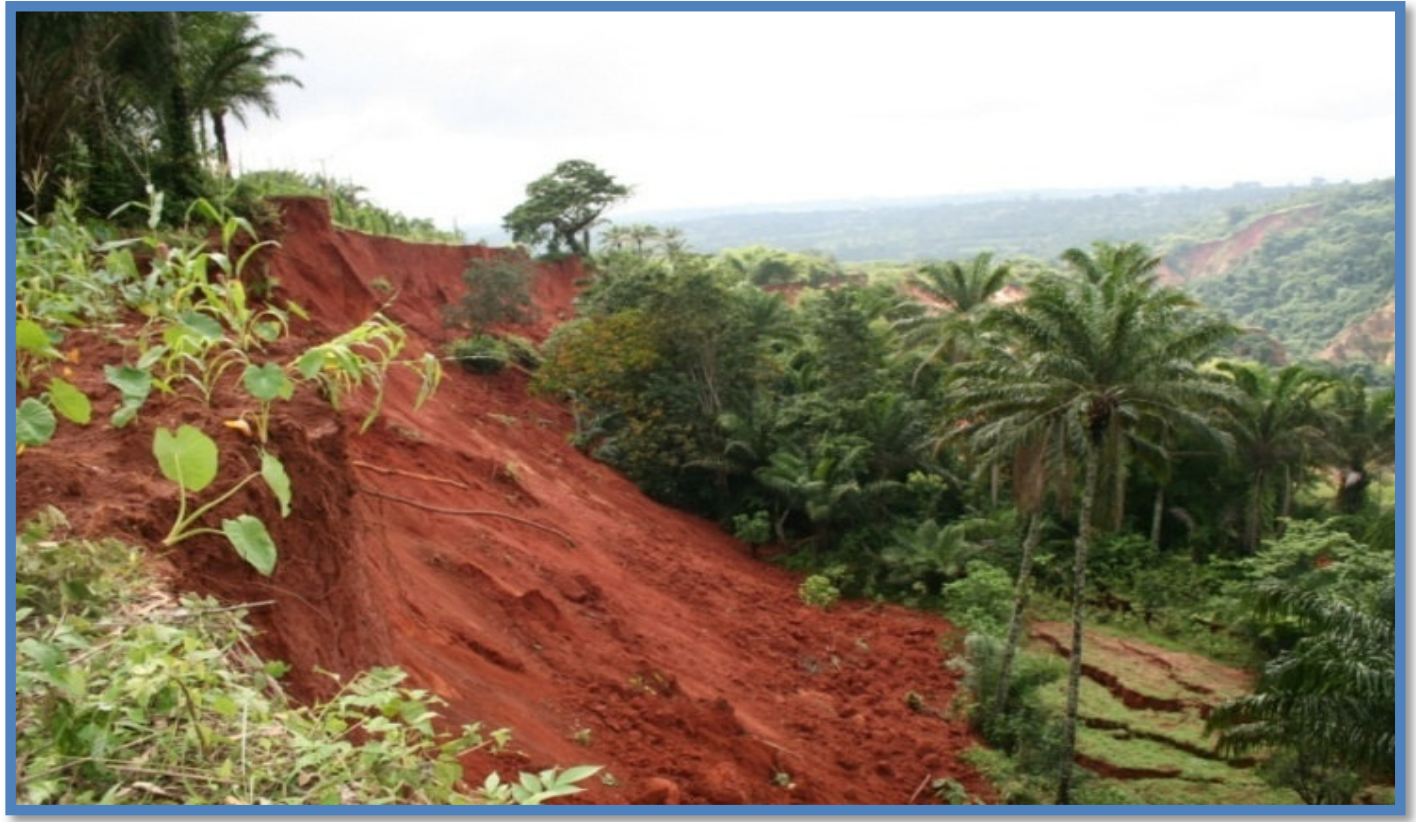

Plate 3.1: Debris slump at Isiakpuenu, Nanka

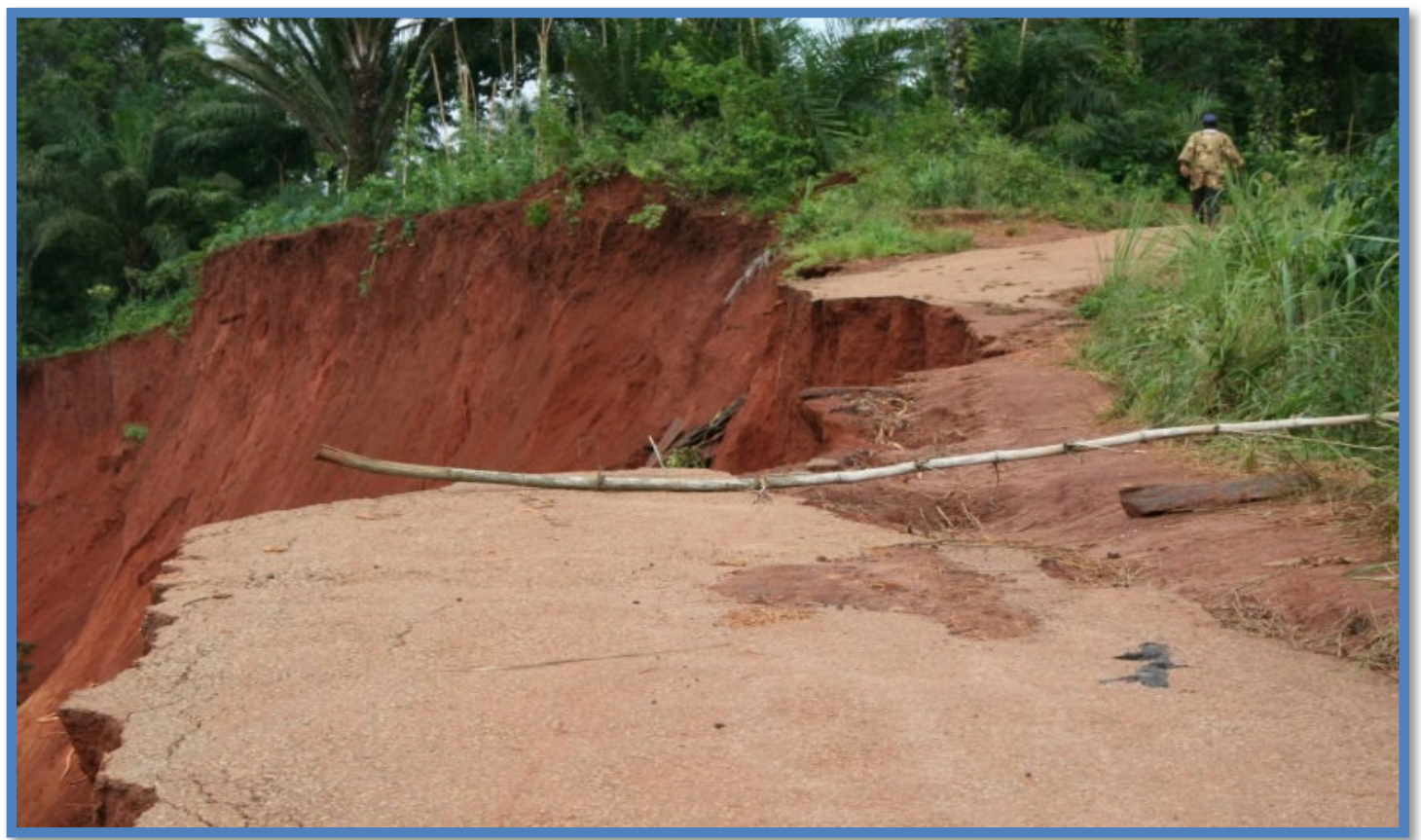

Plate 3.2: Road cut at Isiakpuenu, Nanka 


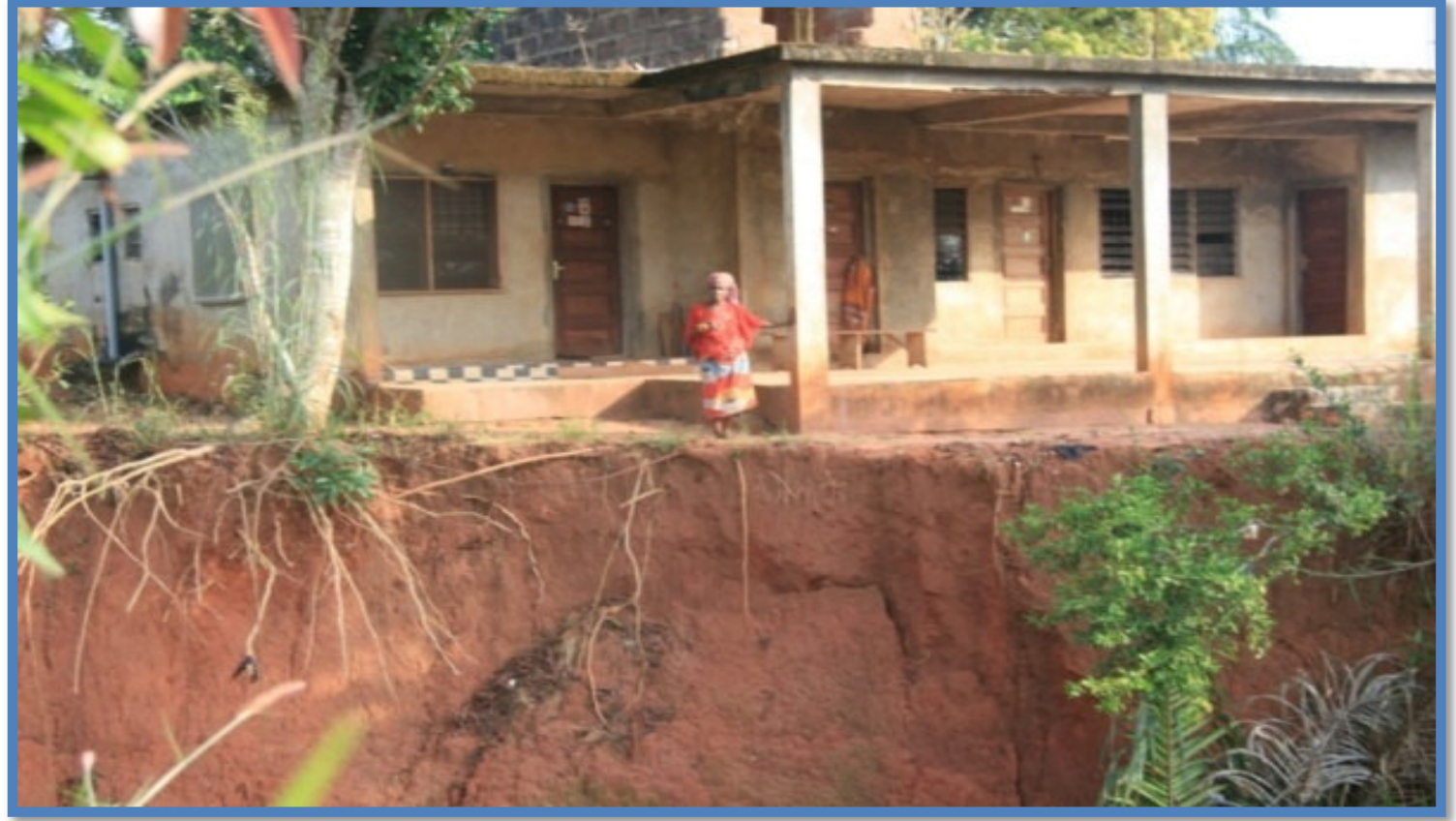

Plate 3.3: Residential Buildings under threat by gully at Amako, Nanka

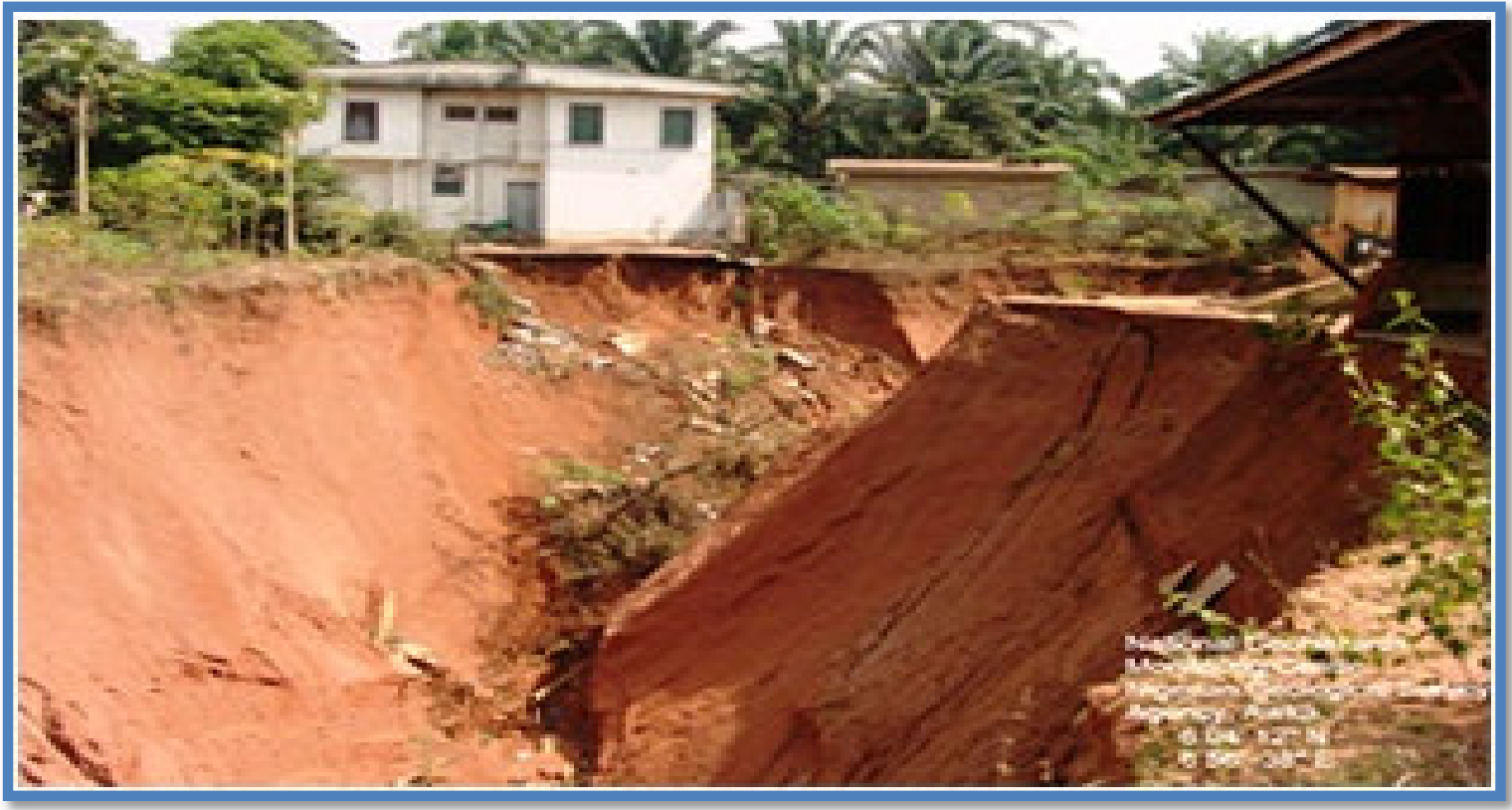

Plate 3.4: Residential Buildings under threat by gully at Amako, Nanka

\section{CHAPTER FIVE}

\subsection{CONCLUSION AND RECOMMENDATION}

\subsection{Conclusion}

As stated, this research study was concerned with the investigation of the causes, effect as well as the control measures of soil erosion in Nanka. It is doubtless that from time immemorial, man has been in contention with nature especially in environmental degradation. Soil erosion is seen as a natural disaster affecting land owners, business holders and the entire inhabitant of Nanka Community.

In the course of the investigation, we discovered that the heavy rainfall throughout the year, poor soil composition, topography, loss of vegetative cover etc. culminated in forming gully erosion in the study area. Gully erosion has caused untold hardship and environmental damage to the residents of the community where several buildings and infrastructures have been destroyed. 
As regards to preventive measures, the government and the inhabitant have devoted much time, resources and energy in mitigating the problems associated with the gully incidence in the study area. Gutters are constructed across different areas especially where there are road networks. Afforestation programmes were employed in curbing the menace, sand filling of gullies, construction of run-off pits in homes and at strategic places in the community, clearing of water channels and public sensitization / awareness campaign as part of the mitigation measures for sustainability and to prevent or reduce future occurrence.

\subsection{Recommendations}

From the study, it is evident that gully erosion as observed has been a continuous, severe and destructive environmental hazard plaguing the inhabitants of the study area. It has defiled all possible solutions employed by the inhabitants of the area. Since environmental hazard as soil erosion do not have local or international boundaries, it is necessary to employ measures that will bring a continuous checking of the increasing problem in the area.

An extensive geology of the area should be done to understand the hydrological map of the area in order to design protective and preventive measures in line with the water courses.

Firstly, the measure already employed in combating soil erosion in the area such as construction of embankment, gutters, drainage networks and sand filling should be upgraded and should be done at the right time.

Secondly, the various levels of government should embark on public enlightenment campaigns through their environmental agent (FEPA) so that the people can be educated on consequences and adverse effects of some activities like deforestation, sand excavations, dumping of refuse in water channels etc.

Thirdly, cover crops trees and flowers should be planted in compounds and along major streets to reduce the rain drop impact on the landscape.

Lastly, individuals should be discouraged from building houses across areas that are prone to soil erosion. This will help to reduce the incidence of exposure of building foundations. Government can achieve this through formulation of bye laws and policies that will act as a guide to the use and misuse of land uses.

\section{References}

Abegunde, A.A (2003): "The Impact of Erosion on Rural on Economy: The Case of Nanka in Anambra State". In urban Finance and Infrastructural Development in Nigeria.YomiFawehinimi (Ed) Atlantis Books.Pp 227-243.

Akpokodje, E.G., Olurunfemi, B.N. \&Etuefeofor, J.O. (1986).Geotechnical properties of soils susceptible to erosion in south eastern Nigeria.Nigerian Jour. Applied Sci. 3(1) p81-95.

Antle and Stooroosel (2001)."Soil Erosion threatens farm land of Sahara Africa" in the Earth Times.

Ananda, J. And Herath, G. (2003). “Soil Erosion in Developing Countries; A socio Economic Appraisal' Journal of Environmental Management, Vol. 68, No. 4, Pp 343-353.

Aneke, D.O. (1986). Coping with accelerated soil erosion in Nigeria. J. Soil Sci. \& Water Conserv. 4(3) p161-163.

Asoegwu, S. N. (1998). Soil Erosion: description, causes and its environmental impact in Southeast Nigeria.

Beijing Time (Peoples daily) (2002) "Soil Erosion, Biggest Global Environmental Problem”. Tuesday, May 28, 2002 in http ://english.people daily.com.cn.

Benneth, S. J. Casali, J. Robinson, K, M, Kudary, K.C. (2000).“Characteristics of Actively Eroded Ephemeral Gullies is on Experimental Channel”. Internal symposium on Gully Erosion under Change.Cath University of Leuven, Belgium, April 16-19.

Bigglar, C., Lai, R., Wiebe K. and Breneneman, V. (2001)."Impact of Soil Erosion on Crop yield in North America". Journal of Advance Agronomy, Vol. 72, Pp. 1-52.

Carter, J. (1958) Erosion and sedimentation from aerial photograph: a microstudy from Nigeria. J. Tropical Geogr. 2, 100-106.

Crosson, P.M. (2003). " Sustainable Agriculture”, Environment, USA. 36(1) P.45

Cunningham, P.W and Cunningham, M.A (2003): Environmental Science: Global Concern Eight Edition New York; Mcgraw-Hill.

Dave, F.M. (2003): "Effects of soil Erosion”. In Http:// Soilerosion.net/ onsite html.

Davis, W.W. (1990). "Environmental impact studies on erosion affected parts of Boston" Geographical Essays. Boston, USA. Pp 771-777.

Egboka, B.C. E (1993) "The raging war" A publication of Anambra State Government of Nigeria, Awka.

Egboka, B.C.E. \&Okpoko.E.G., (1985). Gully erosion Agulu-Nanka region of Anambra State, Nigeria. In: Challenges in African Hydrology and Water Recourses. (Proceedings of the Harare Symposium, July 1984. P 335-347.

Egboka, B.C.E. Nwankwor, G.I., Orajaka I.P., \&Ejiofor, A.O. (1989).Principles and problems of Environmental pollution of groundwater recourses with case examples from developing countries.Environmental Health Perspective Journal. Vol. 83, p 3 9-68.

Egboka, B.C.E., Nwankwor, G.I. \&Orajaka, I.P. (1990). Implications of paleo-and neotectonics in gully Erosion prone area of south eastern Nigeria. Natural Hazards Journal, vol.3,p2 19-231. 
Evans R. (1980): Soil Erosion And Landuse: “Towards A Sustainable Policy”. Cambridge University.

Ezechi, J.F. (2000) "The Influence of Runoff, Lithology and Water Table on the Dimension and Rates of Gullying Processes in Eastern Nigeria" International Symposium on Gully Erosion under Global Change. Cath University of Lerner, Beligium. April 16-19, Pp 28-29.

FAO (1990). "Nigeria: land resources management study. Annex 6: proposals for improved soil and water management in representative (pilot) areas, Appendix 1: The very humid zone," Food and Agriculture Rome. 